\title{
Ecological study on mortality from influenza and pneumonia before and after influenza vaccination in the Northeast and South of Brazil
}

\author{
Estudo ecológico sobre a mortalidade por \\ pneumonia e influenza antes e após a \\ vacinação contra influenza no \\ nordeste e sul do Brasil
}

\section{Estudio ecológico sobre la mortalidad por neumonía e influenza antes y después de la vacunación antigripal en el noreste y el sur de Brasil}

Janessa de Fátima Morgado de Oliveira 1 Antonio Fernando Boing 2 Eliseu Alves Waldman 1 José Leopoldo Ferreira Antunes 1
1 Faculdade de Saúde Pública, Universidade de São Paulo, São Paulo, Brasil. 2 Centro de Ciências da Saúde, Universidade Federal de Santa Catarina, Florianópolis, Brasil.

Correspondence J. L. F. Antunes

Faculdade de Saúde Pública, Universidade de São Paulo. Av. Dr. Arnaldo 715, São Paulo, SP 01246-904, Brasil.

leopoldo@usp.br

\section{Abstract}

The study compared mortality from influenza and pneumonia in elderly people (65 years or older) before and since implementation of influenza vaccination in the South and Northeast regions of Brazil. Official population and mortality data were retrieved from government agencies to estimate weekly mortality rates. The Serfling model was used to identify influenza outbreaks and estimate the mortality attributable to them. In the South, the vaccination period showed a major reduction in mortality from influenza and pneumonia and in the number and duration of influenza outbreaks. These results were interpreted as consistent with the hypothesis of the vaccination program's effectiveness. In the Northeast, there was an increase in mortality from influenza and pneumonia during vaccination, which was associated with a quality improvement in recording causes of death in the elderly. An increase was also seen in mortality attributable to influenza outbreaks, suggesting a mismatch between the period in which vaccination is conducted and the relevant climatic characteristics for influenza transmission.

Human Influenza; Respiratory Tract Diseases; Vaccination; Sazonal Variation

\section{Resumo}

Comparou-se a mortalidade por gripe e pneumonia de idosos (65 anos ou mais) antes e depois do início da vacinação nas regiões Nordeste e Sul do Brasil. Dados oficiais de população e de mortalidade foram recuperados junto às agências governamentais para a estimação de coeficientes semanais de mortalidade. Para a identificação de surtos de gripe e a estimação da mortalidade atribuível a esses surtos, foi utilizado o modelo de Serfling. Na Região Sul, o período com vacinação teve expressiva redução da mortalidade por gripe e pneumonia, e da frequência e duração dos surtos de gripe. Esses resultados foram interpretados como sendo compatíveis com a hipótese de efetividade do programa de vacinação. Na Região Nordeste, houve aumento da mortalidade por gripe e pneumonia durante a vacinação, o que foi associado à melhoria da qualidade do registro das causas de óbito entre idosos. Foi também constatado aumento da mortalidade atribuível aos surtos de gripe, sugerindo inadequação entre o período em que ocorre a vacinação e características climáticas de interesse para a transmissão da gripe.

Influenza Humana; Doenças Respiratórias; Vacinação; Variações Sazonais 


\section{Introduction}

Vaccnation is important for the control of various communicable diseases and is a mandatory component of public health programs 1. Especially for influenza, vaccination was motivated by the favorable recognition of immunization programs for other diseases. Such programs have historically been viewed as successful public health interventions 2 .

Recent years have witnessed important changes in Brazil's demographic structure, particularly with the aging of the country's population, with repercussions on the demand profile for health services ${ }^{3}$. In the elderly population, acute respiratory infections are an important cause of morbidity and mortality. Among these infections, an important proportion is caused by the influenza virus, frequently presenting complications from bacterial infections, resulting in pneumonia and exacerbation of chronic pulmonary and cardiac diseases, leading to hospitalization and even death 2,4. In the North of Brazil, mortality attributable to influenza was estimated at 9.2 per 100,000 persons-year in the elderly (60 years or older). In the South, with greater seasonal variation in climate, the estimate was higher: 86.6 deaths per 100,000 person-years 5 .

Influenza stands out among infectious diseases because of its pandemic potential. This behavior results from its antigenic variability due to frequent mutations, making the human population susceptible to annual epidemics. Annual updating of the vaccine against seasonal influenza thus becomes necessary, since the vaccine's formulation needs to be adjusted to protect against the circulating viral strains. Such adjustment is based on the identification of the most prevalent viral strains in the Southern Hemisphere in order for the vaccine (which is applied in mass campaigns in April and May) to induce its immune response before the colder season, more prone to annual epidemics 6,7 .

Many countries in the Northern Hemisphere with temperate climates continuously document circulation of the influenza virus and its impact on morbidity and mortality. However, few studies have assessed the disease burden and the effectiveness of influenza vaccination in tropical countries, with non-temperate climates ${ }^{8}$. This emphasizes the importance of health surveillance, especially monitoring influenza and vaccination in countries with tropical and temperate climates. Due to its huge territory, Brazil presents relevant climatic variation between its major geographic regions, and these differences have been identified as relevant for orienting public health measures such as the choice of the ideal period for vaccination and use of antiviral drugs 9 .

Vaccination of elderly people aims to decrease influenza incidence, complications of the disease, and mortality in more vulnerable individuals 10,11,12,13. In 1999 (International Year of Older Persons), Brazil's Health Surveillance Secretariat, through the general coordinating body of the National Immunization Program (under the Department of Epidemiological Surveillance, Ministry of Health), launched the annual program for vaccination of the elderly against influenza, with a nationwide scope and extensive community participation 14. Brazil is the country with the highest investment and coverage for vaccination of the elderly, surpassing the $70 \%$ target set by the Ministry of Health 14 . However, few studies have specifically assessed the measure's effectiveness 2,15.

The current study aims to explore hypotheses on the impact of vaccinating the elderly against influenza in Brazil, specifically estimating the reduction in mortality attributable to outbreaks of the disease in the Northeast and South of the country. The study specifically aimed to compare mortality in elderly people (65 years or older) due to influenza and pneumonia before and after annual vaccination was launched in the Northeast and South of Brazil, raising hypotheses on the climatic and socioeconomic differences between the two regions.

\section{Methods}

An ecological study was performed on mortality from influenza and pneumonia in the Northeast and South of Brazil from 1996 to 2008. Official data on mortality from influenza and pneumonia in the elderly (codes J10 to J18 of the International Classification of Diseases, $10^{\text {th }}$ Revision - ICD-10 - used by the Mortality Information System (SIM) since 1996) were collected in the Information Technology Department of the Unified National Health System (DATASUS; http://www.datasus. gov.br) under the Ministry of Health. Official population data were obtained from the Brazilian Institute of Geography and Statistics (IBGE; http://www.ibge.gov.br), as estimated per year by the institute, based on the general population censuses.

Weekly mortality rates were estimated (per 100,000 inhabitants) for the two regions, adjusted by the direct method 16 for differences in distribution of the number of deaths and population according to gender and age (65-69, 70-74, 75-79, and 80 years or older). The reference for the latter 
was the distribution of the Brazilian population in the last year of the study period.

Although the target age group for the influenza vaccination program is 60 years or older, this guideline has only been adopted since 2000, and the 60-64-year group was not included in 19994 . In addition, this age bracket has shown a lower percentage of vaccinated individuals 17 . These observations explain the study's methodological option of focusing on the 65 and older age bracket.

The reference period for the study was 1996 to 2008. The monitoring was not extended further, due to the occurrence of endemic influenza (H1N1) in 2009, which modified the disease's epidemiological profile, thus hindering the current study's comparative analysis for that year.

Likewise, the study did not include data from the years prior to 1996 , due to an important change in the classification criterion for underlying cause of death introduced by the ICD-10. The Pan-American Health Organization (PAHO) recognized that the ICD-10 maintained the same structure from the $9^{\text {th }}$ Revision (ICD-9) and analogous categories for the classification of causes of death; however, the ICD-10 revised the rules for selection of the underlying cause of death, allowing pneumonia and bronchopneumonia to be considered terminal complications of malignant neoplasms, malnutrition, severe traumas, paralyses, and infectious diseases 18 . This change may have led to an important reduction in mortality which, if based on the previous criterion, would have been attributed to pneumonia and bronchopneumonia, with a concomitant increase in mortality due to the above-mentioned conditions 19,20. This observation aims explain the adoption of 1996 as the first year of monitoring, in order to avoid inclusion of data classified by ICD-9, with a presumable impact on the target comparisons for the current study.

To estimate the capacity of the SIM to recognize the underlying cause of death in the target age bracket, for each region we also calculated the annual proportion of sudden deaths from unknown causes, unattended deaths, and deaths from other ill-defined or unspecified causes (respective ICD-10 codes R96, R98, and R99).

Gender and age-adjusted weekly time series were constructed for mortality from influenza and pneumonia in the elderly in the South and Northeast regions. These time series were analyzed for magnitude, tendency, and seasonal variation. Statistical analysis used Stata 12 (Stata Corp., College Station, USA).

To identify outbreaks and estimate mortality specifically attributable to influenza, the study used the classic influenza surveillance model, originally described by Serfling 21 . This method is based on statistical prediction calculated with a simple linear regression equation using harmonic terms. According to this method, for each epidemiological week " $t$ ", estimated mortality $\mathrm{Y}(\mathrm{t})$ is determined by:

$\mathrm{Y}(\mathrm{t})=\mathrm{b} 0+\mathrm{b} 1 \times \mathrm{t}+\mathrm{b} 2 \times \cos 2 \varpi \mathrm{t} / 52+\mathrm{b} 3 \times \operatorname{sen} 2 \omega \mathrm{t} / 52+\mathrm{b} 4$ $\times \cos 4 \varpi t / 52+b 5 \times \operatorname{sen} 4 \omega t / 52+\varepsilon$,

where b0 is the intercept of the regression analysis, b1 is the linear trend coefficient, b2-b5 the coefficients of seasonal variation, and $\varepsilon$ the residual of the regression analysis.

The estimation is subsequently enhanced by the exclusion of the mortality observed during epidemic outbreaks, and readjustment of the equation. The epidemic threshold is calculated as the sum of the estimated values and the product of 1.645 ( $\mathrm{z}$ value in the normal distribution corresponding to $95 \%$ likelihood of not occurring even higher values) and the standard deviation of the estimated values for each week.

Epidemic outbreaks of influenza are recognized when the observed mortality exceeds the epidemic threshold for at least two consecutive weeks. Excess mortality in influenza outbreaks is defined as the difference between the rates observed during epidemic weeks and the values predicted by the regression equation 21 . The values obtained with this method were compared between the regions and between the periods with and without vaccination.

\section{Results}

Table 1 shows the magnitude of mortality in the elderly due to influenza and pneumonia in the Northeast and South during the three-year period preceding the program and in the subsequent years. The mortality rates were systematically higher in the South, both before and after vaccination was implemented (Figures 1 and 2). This region showed a $15.7 \%$ decline in the mean annual rate after introduction of the vaccine. However, the Northeast showed a 51\% increase, indicating that there were more deaths attributed to influenza and pneumonia after introduction of the vaccine.

Figures 1 and 2 indicate differences in seasonal variation between the two regions: in the Northeast, variation between seasons of the year was smaller, and the period with the highest mortality occurred earlier than in the South. In both periods, estimated mortality in the South reached its peak values between the $28^{\text {th }}$ and $31^{\text {st }}$ epidemiological weeks, corresponding to win- 
Mortality from pneumonia and influenza in the elderly (65 years or older): number of deaths and mortality rates (per 100,000 inhabitants) in the South and Northeast regions of Brazil before (1996-1998) and during influenza vaccination (1999-2009).

\begin{tabular}{|c|c|c|c|c|}
\hline & \multicolumn{2}{|c|}{ South } & \multicolumn{2}{|c|}{ Northeast } \\
\hline & Deaths & Mortality rate & Deaths & Mortality rate \\
\hline \multicolumn{5}{|l|}{ Before vaccination } \\
\hline 1996 & 3,081 & 254.64 & 1,678 & 66.76 \\
\hline 1997 & 2,568 & 203.17 & 1,561 & 60.42 \\
\hline 1998 & 2,897 & 219.83 & 1,920 & 72.08 \\
\hline Mean annual rates & & 225.88 & & 66.42 \\
\hline \multicolumn{5}{|l|}{ During vaccination } \\
\hline 1999 & 2,497 & 180.87 & 2,035 & 74.35 \\
\hline 2000 & 2,469 & 170.30 & 2,035 & 72.32 \\
\hline 2001 & 2,580 & 170.38 & 2,143 & 74.20 \\
\hline 2002 & 2,701 & 170.65 & 2,517 & 84.86 \\
\hline 2003 & 3,015 & 183.18 & 2,653 & 86.96 \\
\hline 2004 & 3,315 & 192.46 & 3,017 & 96.26 \\
\hline 2005 & 3,483 & 192.59 & 3,319 & 102.92 \\
\hline 2006 & 4,024 & 213.52 & 4,148 & 125.36 \\
\hline 2007 & 4,375 & 222.36 & 4,679 & 137.63 \\
\hline 2008 & 4,298 & 208.87 & 5,168 & 147.81 \\
\hline Mean annual rates & & 190.52 & & 100.27 \\
\hline Variation between periods & & $-15.65 \%$ & & $+50.96 \%$ \\
\hline
\end{tabular}

ter (approximately the $3^{\text {rd }}$ week of July to the $2^{\text {nd }}$ week of August). In the Northeast, peak mortality from influenza and pneumonia in the elderly occurred between the 17th and 22nd epidemiological weeks, corresponding to autumn (approximately the $4^{\text {th }}$ week of April to the $4^{\text {th }}$ week of May). These results are indicative of differences in the epidemiological profile of acute respiratory diseases in each region.

Table 2 describes the number of outbreaks attributable to influenza in the two periods and in the two regions. Data for the period preceding vaccination show two peaks (excess mortality from influenza and pneumonia) attributable to influenza outbreaks in relation to expected values according to the models in the South, and four in the Northeast. The mean duration of these outbreaks and the excess mortality associated with them were higher in the South than in the Northeast.

During the period in which the vaccination program was active, there was a substantial reduction in the indicators in the South: $55.2 \%$ fewer outbreaks, on average, per year; $86.1 \%$ shorter outbreaks, measured in number of weeks; and $98.9 \%$ fewer annual deaths attributed to these outbreaks. In the Northeast, the mortality attrib- utable to influenza outbreaks increased during the period with vaccination.

The difference between the variation profiles in mortality from influenza and pneumonia in the two regions was accompanied by a striking contrast in the proportion of deaths from ill-defined and unspecified causes. At the beginning of the study period, more than one-third of annual deaths in elderly people in the Northeast were classified in this category. This proportion subsequently decreased, more intensely after 2004, reaching $10 \%$ by the end of the study period. In the South, this measure also decreased during the study period, but at a lower level, always below $10 \%$ (Figure 3 ).

\section{Discussion}

The study showed that the introduction of influenza vaccination in the South of Brazil was accompanied by an important reduction in mortality from influenza and pneumonia in the elderly, in the mean number of annual influenza outbreaks, in the mean duration of outbreaks, and in the mortality attributable to them. The study also showed that equivalent reductions failed 
Figure 1

Weekly mortality from influenza and pneumonia in the elderly (65 years or older) during the period without vaccination (1996-1998): observed weekly rates, predicted baseline, and epidemic threshold (Serfling model).
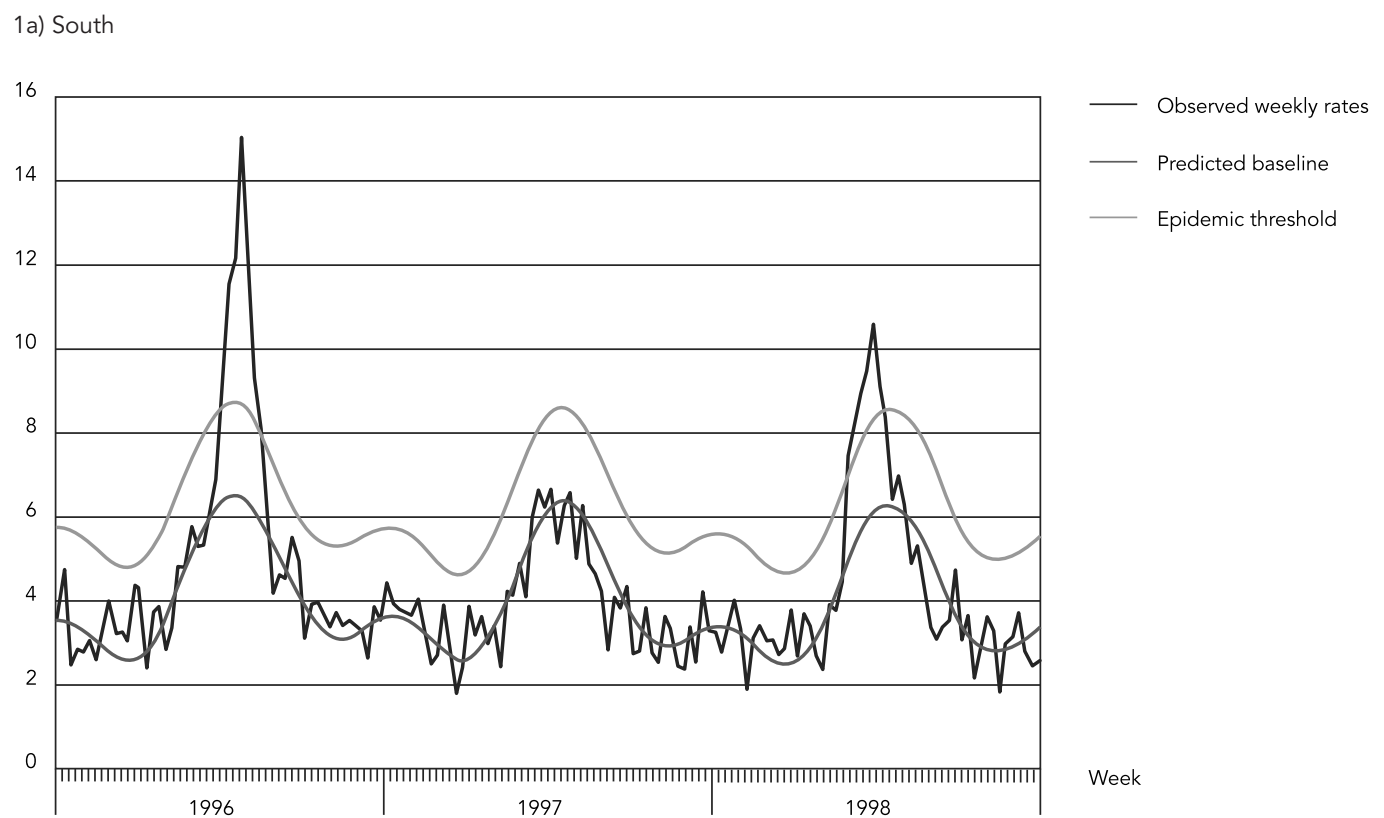

1b) Northeast
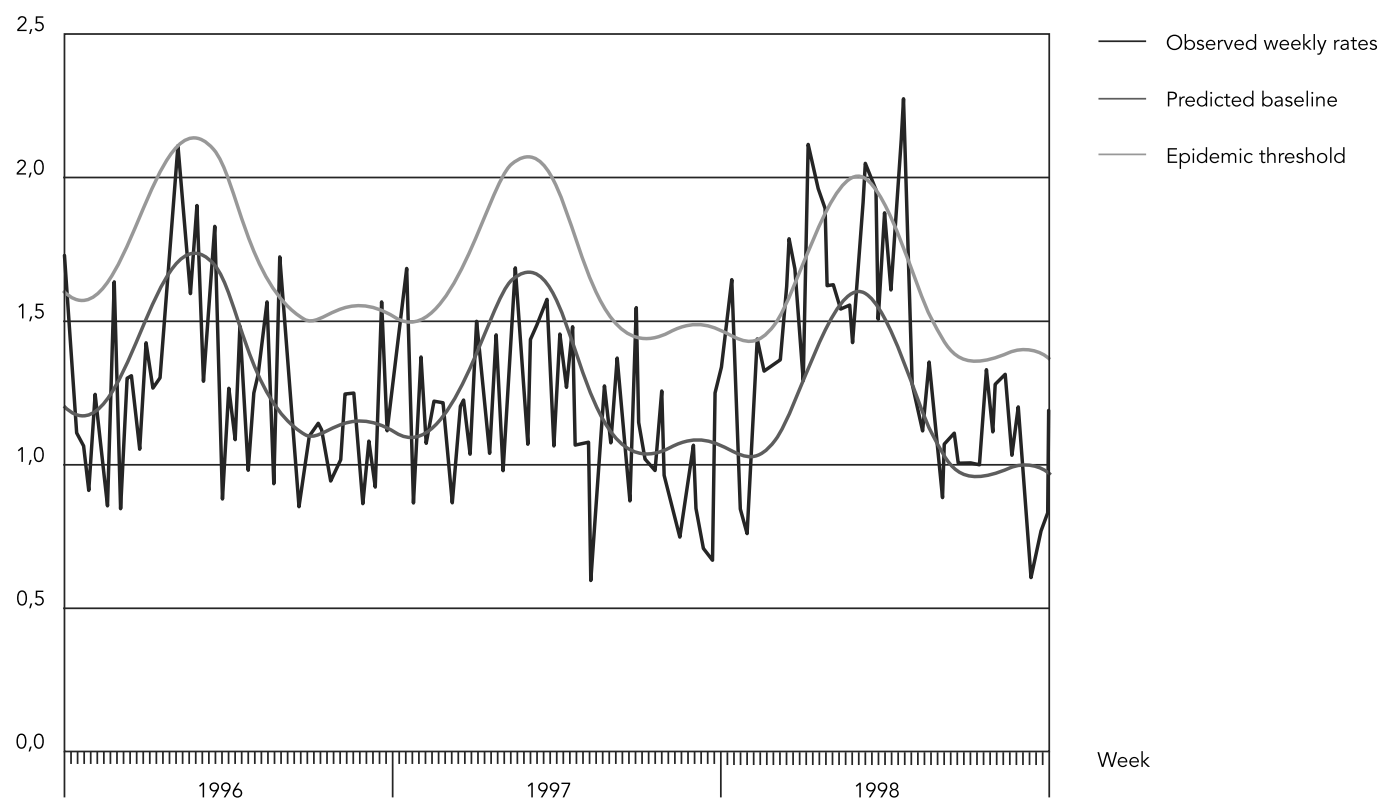

Week 
Figure 2

Weekly mortality from influenza and pneumonia in the elderly (65 years or older) during the period with vaccination (1999-2008): observed weekly rates, predicted baseline, and epidemic threshold (Serfling model).

2a) South
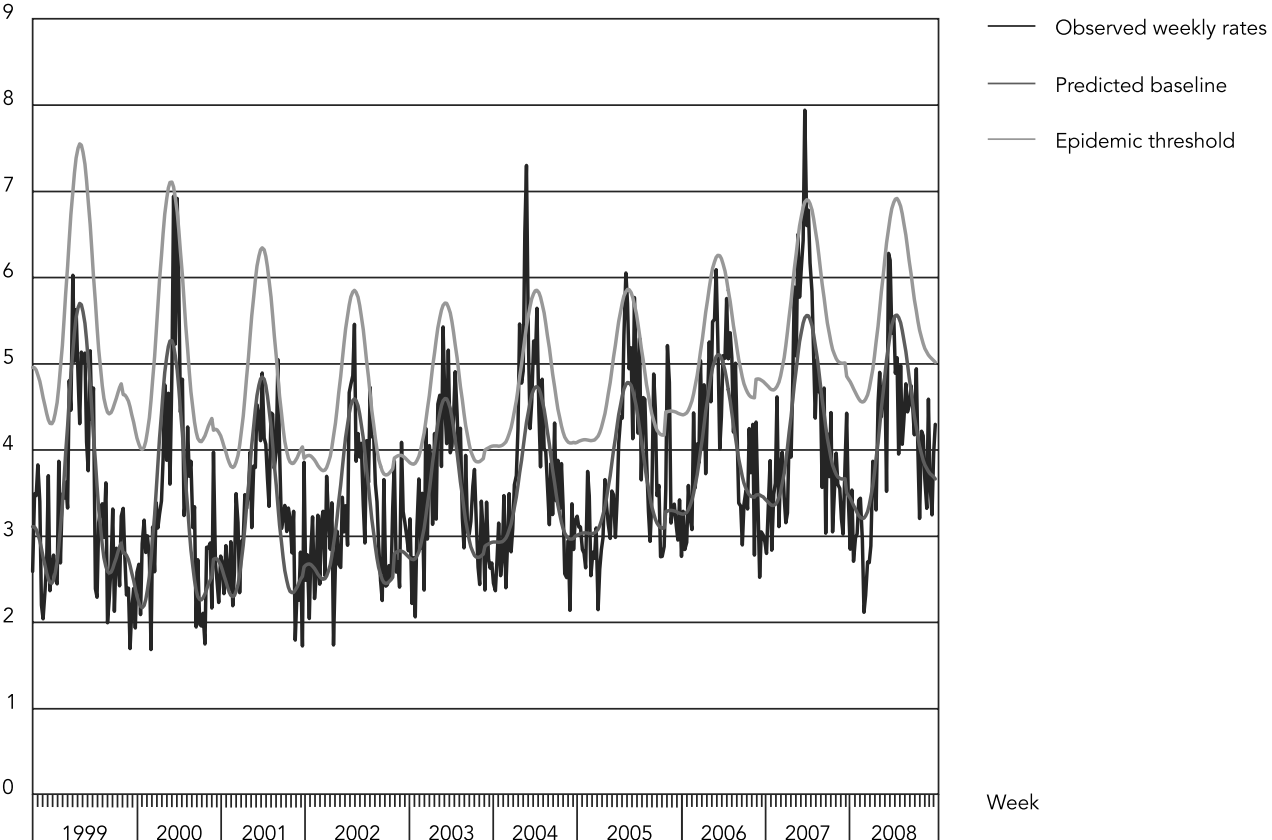

2b) Northeast
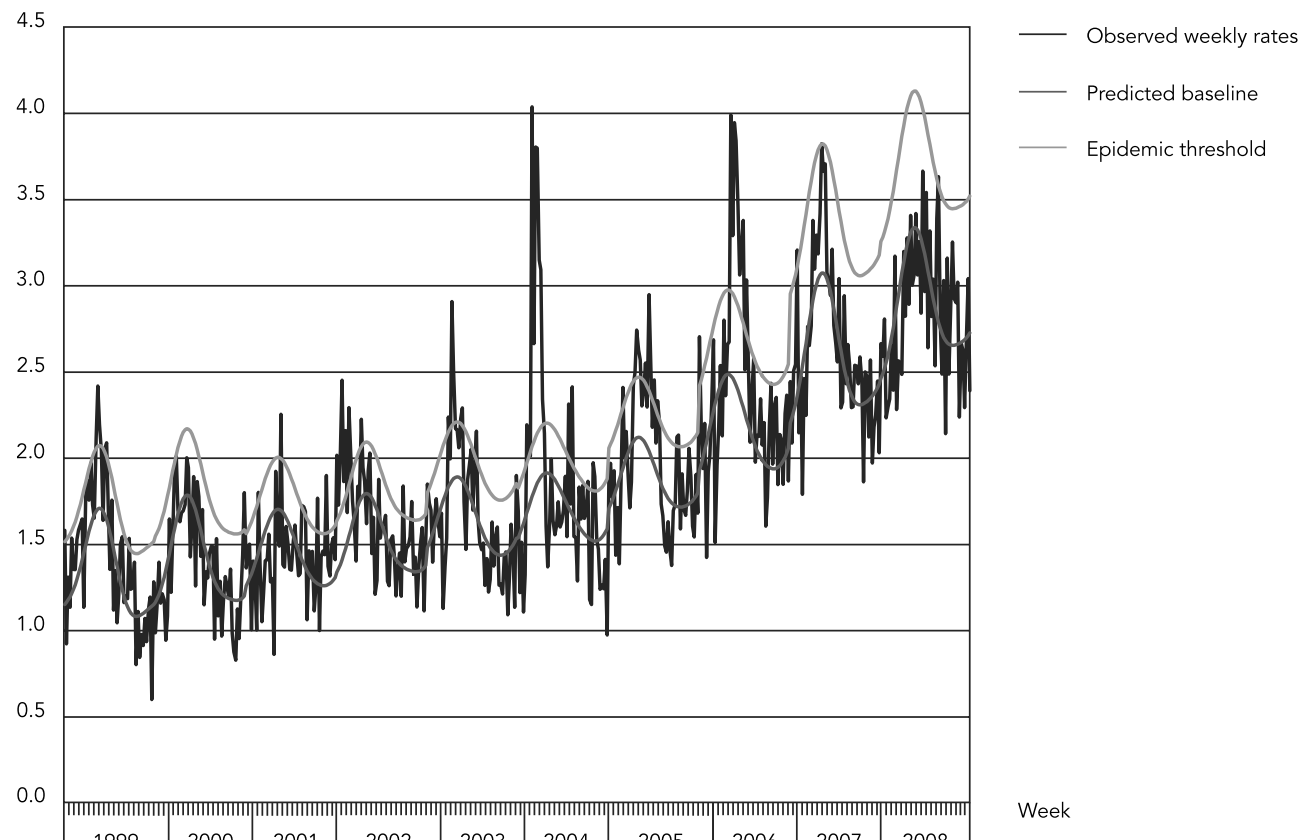
Table 2

Number of outbreaks, duration of outbreaks, and estimated excess mortality attributed to influenza in the elderly (65 years or older) according to the Serfling model in the South and Northeast of Brazil, 1996-2009.

\begin{tabular}{lcccccc}
\hline & South & & & Northeast \\
& Outbreaks & Weeks & Excess deaths & Outbreaks & Weeks & Excess deaths \\
\hline $\begin{array}{l}\text { Before vaccination } \\
1996\end{array}$ & 1 & & & & \\
1997 & 0 & 0 & 239 & 0 & 0 & 0 \\
1998 & 1 & 0 & 96 & 3 & 2 & 6 \\
Annual mean & 0.67 & 4.33 & 111.67 & 1.33 & 3.67 & 19.33 \\
During vaccination & & & & & \\
1999 & 0 & 0 & 0 & 2 & 5 & 17 \\
2000 & 0 & 0 & 0 & 0 & 0 & 0 \\
2001 & 0 & 0 & 0 & 1 & 3 & 2 \\
2002 & 0 & 0 & 0 & 2 & 8 & 76 \\
2003 & 0 & 0 & 0 & 2 & 4 & 35 \\
2004 & 1 & 2 & 56 & 3 & 11 & 256 \\
2005 & 1 & 2 & 14 & 3 & 8 & 46 \\
2006 & 1 & 2 & 21 & 1 & 8 & 163 \\
2007 & 0 & 0 & 0 & 0 & 0 & 0 \\
2008 & 0 & 0 & 0 & 0 & 0 & 0 \\
Annual mean & 0.30 & 0.60 & 9.10 & 1.40 & 4.70 & 59.50 \\
Variation between periods & $-55.22 \%$ & $-86.14 \%$ & $-91.85 \%$ & $+5.26 \%$ & $+28.07 \%$ & $+207.81 \%$ \\
\hline
\end{tabular}

Figure 3

Annual proportion of deaths in the elderly (65 years or older) due to ill-defined or unspecified causes in the Northeast and South of Brazil, 1996-2008.

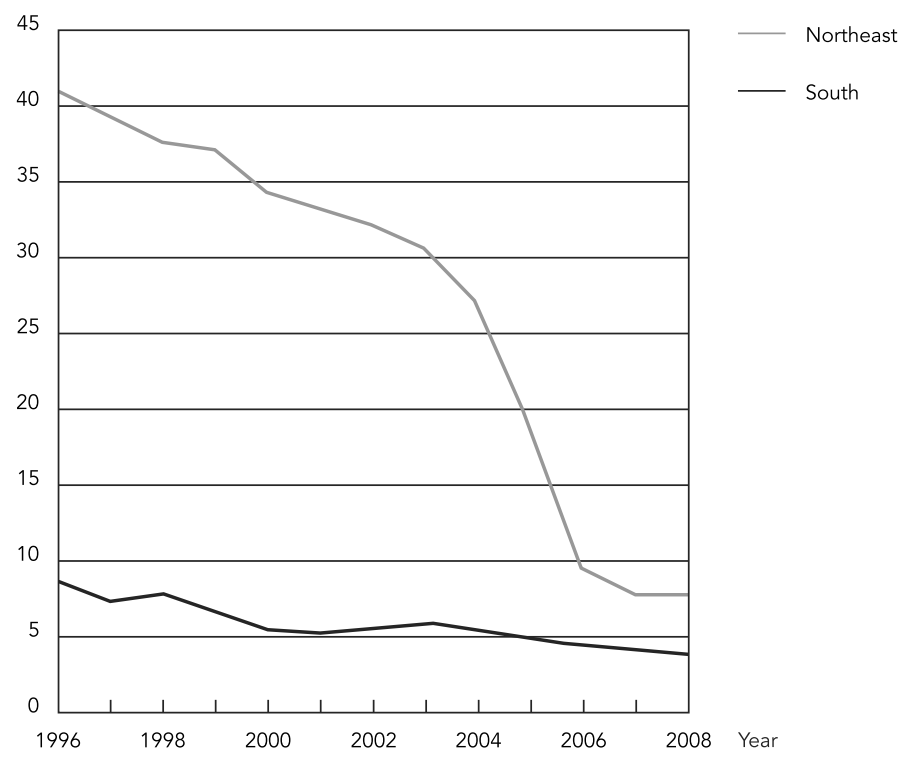


to occur in the Northeast. On the contrary, the Northeast showed an important increase in all these indicators during the vaccination period. The contrast between the epidemiological profiles of influenza in the elderly in the two regions is this study's most important result.

The findings in the South are consistent with the hypothesis of the effectiveness of the annual influenza vaccination program in the elderly, corroborating previous studies. Ferrer et al. 22 observed a significant reduction in morbidity from respiratory diseases in the elderly in the State of Paraná after the annual vaccination program was introduced. Campagna et al. 11 reported a persistent decrease in mortality from pneumonia, influenza, bronchitis, and upper airway obstruction in the elderly during the period with vaccination, for Brazil as a whole and especially for the South and Southeast regions.

On the other hand, the results for the Northeast were not consistent with the hypothesis of the effectiveness of the annual vaccination program. This observation was also made in previous studies on the epidemiological profile of influenza in Northeast Brazil. Façanha 23 compared data on hospitalizations and deaths from 1995 to 2001 and found that vaccination of the elderly against influenza in Fortaleza, Ceará State, failed to produce favorable results. Based on a systematic literature review, Luna \& Gattás 24 found that no reduction occurred in mortality and hospitalizations from influenza-related causes in the North and Northeast of Brazil.

In Brazil, influenza surveillance has been substantially intensified since the 1990s, when mass vaccination became feasible and was in fact implemented. However, the effectiveness of influenza vaccination in the elderly is still subject to international controversy and debate. These observations reinforce the importance of studies providing new results on this question.

In the 1990s, influenza vaccination was assessed as one of the medical interventions with the best cost-effectiveness ratio in the elderly population 7 . A meta-analysis on the vaccine's efficacy concluded that immunization against influenza was an indispensable part of healthcare for the elderly 25 . However, a later systematic review concluded that evidence in favor of the measure was only modest for communitydwelling elderly, and that it should only be recommended for elderly persons living in nursing homes and similar facilities ${ }^{8}$. In the United States, the Centers for Disease Control and Prevention (CDC) reiterated that influenza vaccination was more effective for elderly residents of long-term institutions, but also acknowledged its favorable effect in reducing the secondary complications of influenza, hospitalization, and death 26,27 .

The current study provided an ecological time series analysis of mortality in two major geographic regions of Brazil. This design was not intended (nor is it able) to establish cause-andeffect relations. It is thus important to highlight a first limitation to the study, i.e., that it is only capable of analytically exploring hypotheses and mortality trends from influenza and pneumonia in the periods before and after the introduction of vaccination.

The analysis of influenza-associated mortality also displays limitations due to some characteristics of the disease. Its serious complications, such as bacterial pneumonia, are often diagnosed late or even without having identified primary infection with the influenza virus. It is estimated that major underreporting occurs with influenza-related hospitalizations and deaths 8 , thus justifying the evaluation of excess mortality from influenza and pneumonia during periods with outbreaks, as a proxy for deaths caused by influenza. This justifies monitoring seasonal variation, as done in the current study. This difficulty poses a limitation for all studies that aim to estimate the magnitude of mortality associated with this viral disease, a strategy widely used in influenza surveillance.

Another important limitation, especially in the Northeast, is the high proportion of deaths in the elderly in which the underlying causes were not objectively determined. The mortality system's lower capacity to identify the underlying cause of death may have been one of the factors explaining the lower magnitude of mortality from influenza and pneumonia in the elderly in the Northeast as compared to the South, which has been reported in other studies ${ }^{5}$. It is plausible that the increase in mortality from influenza and pneumonia in the Northeast is related to the steady reduction in the proportion of deaths in the elderly without identification of the underlying cause of death. Caution is thus recommended in interpreting the increase in mortality in the elderly associated with influenza outbreaks in the Northeast during the period with vaccination.

Quality improvement in recording causes of death does not explain the increase in mortality specifically attributable to influenza outbreaks in the Northeast. Rather, this increase in mortality suggests a flaw in the effectiveness of the strategy applied by the vaccination program in this region. In particular, there may be a mismatch between the season in which vaccination is conducted and the seasonal characteristics of influenza virus circulation in the region, different from the South and Southeast of Brazil 11,24,28. 
According to the current study, the phase with the highest estimated mortality from influenza and pneumonia occurs nearly three months earlier in the Northeast than in the South. In fact, previous studies had already shown a latitudinal gradient between the phases with the highest concentration of the disease in the regions of Brazil 5,28,29, attributing this difference to the regions' respective climatic characteristics. Although there is no low-temperature season in the Northeast, seasonal increase in influenza transmission during the rainiest season has also been recorded in other studies 30,31 .

In the South, the climate is subtropical, with more temperate characteristics: considerable variation in temperature over the year, mean annual temperature close to $20^{\circ} \mathrm{C}$, and $1,800 \mathrm{~mm}$ in annual rainfall, with rains distributed throughout the region's territory 28,29 . In the South, the season with the highest concentration of influenza is the winter, when the relative humidity is lower and the colder temperatures favor more contact in closed environments, thus in conditions that are more prone to transmission of respiratory infections.

The climate in the Northeast is tropical, with little variation in temperature over the year, a mean of some $25^{\circ} \mathrm{C}$, and some $1,000 \mathrm{~mm}$ annual rainfall, mostly occurring in the autumn and along the coast, precisely the part of the region with the highest population density ${ }^{3}$. The slight temperature drop during the winter and the greater concentration of rains (and also contact in closed environments) could explain the differences in seasonal variation in influenza between the two regions 28,29 .

One to two weeks after vaccination, protective antibodies can already be detected in healthy adults, but peak concentration only occurs four to six weeks after vaccination 32 . However, annual vaccination traditionally occurs throughout Brazil in the first two weeks of April (between the 14th and $17^{\text {th }}$ epidemiological weeks). The timetable is well adjusted to the phase with highest influenza mortality in the South (28th to 31 st epidemiological weeks), but it is too late for the Northeast (17th to 22nd epidemiological weeks).

These observations highlight the need for regional adjustment of the program in coming years, in order to increase its effectiveness. When vaccination occurs, viral circulation is already at its highest phases, without sufficient time to mount an effective immune response at the population level. Mello et al. 29 also observed the need to anticipate vaccination, even if it requires adopting the vaccine composition recommended for the Northern Hemisphere. Adjustment of the time of vaccination to the time of greatest viral circulation is a critical question that influences the vaccine's effectiveness and should be considered in Brazil's health planning. 


\section{Resumen}

Se comparó la mortalidad por influenza y neumonía en adultos mayores (65 años o más) antes y después del inicio de la vacunación en el Noreste y Sur de Brasil. Datos oficiales sobre población y muertes fueron recuperados de agencias gubernamentales para estimar las tasas de mortalidad semanales. Se utilizó el modelo Serfling para identificar brotes de gripe y evaluar la mortalidad atribuible a esos brotes. En el Sur, hubo una reducción significativa de la mortalidad por influenza y neumonía y en la frecuencia y duración de los brotes de influenza en el periodo de vacunación, lo que sugiere la eficacia de la eficacia del programa de vacunación. En el Nordeste, el aumento de la mortalidad por influenza y neumonía durante la vacunación se explica por la mejora en la calidad del registro de causas de muerte entre las personas mayores. La mortalidad atribuible a los brotes de influenza también se incrementó durante la vacunación, lo que sugiere una falta de coincidencia entre el período de vacunación y características climáticas de interés para la transmisión de la gripe.

Gripe Humana; Enfermedades Respiratórias;

Vacunación; Variaciones Estacionales

\section{References}

1. Sorvillo F, Shafir S. Control of microbial threats: population surveillance, vaccine studies, and the microbiological laboratory. In: Detels R, Beaglehole R, Lansang MA, Gulliford M, editors. Oxford textbook of public health. $5^{\text {th }}$ Ed. Oxford: Oxford University Press; 2009. p. 858-71.

2. Cunha SS, Camacho LAB, Santos AC, Dourado I. Influenza vaccination in Brazil: rationale and caveats. Rev Saúde Pública 2005; 39:129-36.

3. Mendes ACG, Sá DA, Miranda GMD, Lyra TM, Tavares RAW. Assistência pública de saúde no contexto da transição demográfica brasileira: exigências atuais e futuras. Cad Saúde Pública 2012; 28:955-64.

4. Fiore AE, Shay DK, Broder K, Iskander JK, Uyeki TM, Mootrey G, et al. Prevention and control of influenza: recommendations of the Advisory Committee on Immunization Practices, 2008. MMWR Recomm Rep 2008; 57:1-60.

5. Freitas FTM, Souza LRO, Azziz-Baumgartner E, Cheng PY, Zhou H, Widdowson MA, et al. Influenza-associated excess mortality in southern Brazil, 1980-2008. Epidemiol Infect 2013; 141:1731-40.

\section{Contributors}

J. F. M. Oliveira and J. L. F. Antunes participated in the study planning, data collection and analysis, and writing of the manuscript. A. F. Boing collaborated in the study planning, data collection and analysis, and writing of the manuscript. E. A. Waldman contributed to the study planning, data analysis, and writing of the manuscript.
6. Carrat F, Flahault A. Influenza vaccine: the challenge of antigenic drift. Vaccine 2007; 25:6852-62.

7. Gerdil C. The annual production cycle for influenza vaccine. Vaccine 2003; 21:1776-9.

8. Simonsen L. The global impact of influenza on morbidity and mortality. Vaccine 1999; 17 Suppl 1:S3-10.

9. Freitas FTM. Sentinel surveillance of influenza and other respiratory viruses, Brazil, 2000-2010. Braz J Infect Dis 2013; 17:62-8.

10. Jefferson T, Rivetti D, Rivetti A, Rudin M, Di Pietrantonj C, Demicheli V. Efficacy and effectiveness of influenza vaccines in elderly people: a systematic review. Lancet 2005; 366:1165-74.

11. Campagna AS, Dourado I, Duarte EC, Daufenbach LZ. Mortalidade por causas relacionadas à influenza em idosos no Brasil, 1992 a 2005. Epidemiol Serv Saúde 2009; 18:209-18.

12. Francisco PMSB, Donalisio MR, Barros MBA, César CLG, Carandina L, Goldbaum M. Vacinação contra influenza em idosos por área de residência: prevalência e fatores associados. Rev Bras Epidemiol 2006; 9:162-71. 
13. Dip RM, Cabrera MAS. Influenza vaccination in non-institutionalized elderly: a population-based study in a medium-sized city in Southern Brazil. Cad Saúde Pública 2010; 26:1035-44.

14. Donalisio MR. Política brasileira de vacinação contra a Influenza e seu impacto sobre a saúde do idoso. Cad Saúde Pública 2007; 23:494-5.

15. Antunes JLF, Waldman EA, Borrell C, Paiva TM. Effectiveness of influenza vaccination and its impact on health inequalities. Int J Epidemiol 2007; 36:1319-26.

16. Laurenti R, Mello-Jorge MHP, Lebrão ML, Gotlieb SLD. Estatísticas de saúde. São Paulo: E.P.U.; 1987.

17. Donalisio MR, Ruiz T, Cordeiro R. Fatores associados à vacinação contra influenza em idosos em município do Sudeste do Brasil. Rev Saúde Pública 2006; 40:115-9.

18. Revisions of the International Classification of Diseases (ICD-9 and ICD-10): impact on health statistics. Epidemiol Bull 1996; 17:1-5.

19. Geran L, Tully P, Wood P, Thomas B. Comparability of ICD-10 and ICD-9 for mortality statistics in Canada. Ottawa: Health Statistics Division, Statistics Canada; 2005.

20. Cano-Serral G, Perez G, Borrell C; COMPARA Group. Comparability between ICD-9 and ICD-10 for the leading causes of death in Spain. Rev Epidemiol Sante Publique 2006; 54:355-65.

21. Serfling RE. Methods for current statistical analysis of excess pneumonia-influenza deaths. Public Health Rep 1963; 78:494-506.

22. Ferrer ALM, Marcon SS, Santana RG. Hospital morbidity among elderly patients, before and after influenza vaccination in the State of Paraná. Rev Latinoam Enferm 2008; 16:832-7.

23. Façanha MC. Impacto da vacinação de maiores de 60 anos para influenza sobre as internações e óbitos por doenças respiratórias e circulatórias em Fortaleza - CE - Brasil. J Bras Pneumol 2005; 31:415-20.

24. Luna EJA, Gattás VL. Effectiveness of Brazilian influenza vaccination policy, a systematic review. Rev Inst Med Trop São Paulo 2010; 52:175-81.
25. Gross PA, Hermogenes AW, Sacks HS, Lau J, Levandowski RA. The efficacy of influenza vaccine in elderly persons. A meta-analysis and review of the literature. Ann Intern Med 1995; 123:518-27.

26. Bridges CB, Fukuda K, Cox NJ, Singleton JA; Advisory Committee on Immunization Practices. Prevention and control of influenza: recommendations of the Advisory Committee on Immunization Practices (ACIP). MMWR Recomm Rep 2001; 50:1-44.

27. Fiore AE, Shay DK, Haber P, Iskander JK, Uyeki TM, Mootrey G, et al. Prevention and control of influenza: recommendations of the Advisory Committee on Immunization Practices (ACIP), 2007. MMWR Recomm Rep 2007; 56:1-54.

28. Alonso WJ, Viboud C, Simonsen L, Hirano EW, Daufenbach LZ, Miller MA. Seasonality of influenza in Brazil: a traveling wave from the Amazon to the Subtropics. Am J Epidemiol 2007; 165:1434-42.

29. Mello WA, Paiva TM, Ishida MA, Benega MA, Santos MC, Viboud C, et al. The dilemma of influenza vaccine recommendations when applied to the tropics: the Brazilian case examined under alternative scenarios. PLoS ONE 2009; 4:e5095.

30. Moura FE, Perdigão AC, Siqueira MM. Seasonality of influenza in the tropics: a distinct pattern in northeastern Brazil. Am J Trop Med Hyg 2009; 81:180-3.

31. Alonso WJ, Laranjeira BJ, Pereira SA, Florencio CM, Moreno EC, Miller MA, et al. Comparative dynamics, morbidity and mortality burden of pediatric viral respiratory infections in an equatorial city. Pediatr Infect Dis J 2012; 31:e9-14.

32. Goronzy JJ, Fulbright JW, Crowson CS, Poland GA, O'Fallon WM, Weyand CM. Value of immunological markers in predicting responsiveness to influenza vaccination in elderly individuals. J Virol 2001; 75:12182-7.

Submitted on 12/Feb/2013

Final version resubmitted on 17/Jun/2013

Approved on 12/Jul/2013 